\title{
Freedom of Religion as a Human Rights Protection in Indonesia
}

\author{
Amri Panahatan Sihotang ${ }^{1}$, B. Rini Heryanti ${ }^{*}$, Subaidah Ratna Juita ${ }^{1}$ \\ ${ }^{1}$ Faculty of Law, Universitas Semarang, Semarang, Indonesia \\ *Corresponding author. Email: b.rini.heryanti@gmail.com
}

\begin{abstract}
The normative theoretical discussion and study of the refusal of freedom of religion and belief in Indonesia is proof that there are some people in Indonesia who have not been able to accept diversity / plurality. The study entitled " Strength of Religious Freedom in Indonesia as a Human Rights Violation in Indonesia" was carried out with a normative juridical approach to secondary data. Secondary data is obtained through legislation, books, and scientific journals. The data collection method used is through literature study. Data analysis method uses descriptive analysis. Thus, the juridical-sociological approach in this study is used to analyze problems related to the conditions (in) the lack of religious freedom reflects the complexity of relations between countries and religions in Indonesia and as a form of violation of Human Rights (HAM).

Keywords: strength, religious, Human Rights
\end{abstract}

\section{INTRODUCTION}

The state has the duty and responsibility to regulate religious differences and differences. Countries that make various laws and policies that can accommodate and support this diversity, but on one side of the country in favor of one particular religion, so it needs to be discussed about religious freedom. In addition, the lack of a pluralist understanding in society also narrows the area of religious freedom in Indonesia. Not a few of the people who have not yet determined the matter of religious freedom and the Law which approved that freedom. Therefore, opposing some people even judge others on behalf of religion without understanding the law.

The rejection of freedom of religion and belief in Indonesia is one of the proofs of some Indonesian people who have not been able to accept such diversity / plurality. The freedom of religion and the diversity of religions and beliefs that we encounter in Indonesia cannot be taken for granted by some parties. There are still other religious parties / groups that continue to change parties / other religious groups.

\section{RESEARCH METHOD}

The method of approach that will be used in this study is a normative juridical approach, namely by studying or analyzing secondary data in the form of primary legal material, by understanding the law as a set of rules or positive norms in the legal system governing freedom of religion as a violation Human rights, as well as using secondary and tertiary legal materials. 2. Data Collection and Analysis Methods

Data collection method is done through literature study. Data collected is secondary data. Research data in the form of secondary data will be analyzed qualitatively then identified and categorized. From the results of the analysis, conclusions will be drawn in response to existing problems.

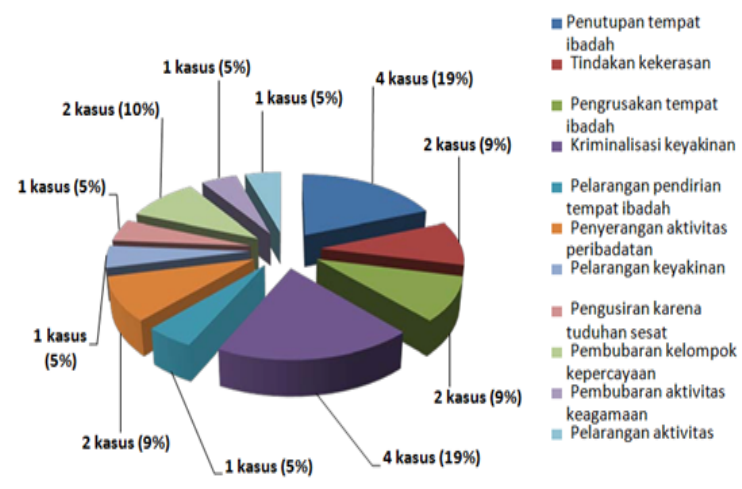

Figure 1 Forms of Violation of Freedom of Religion

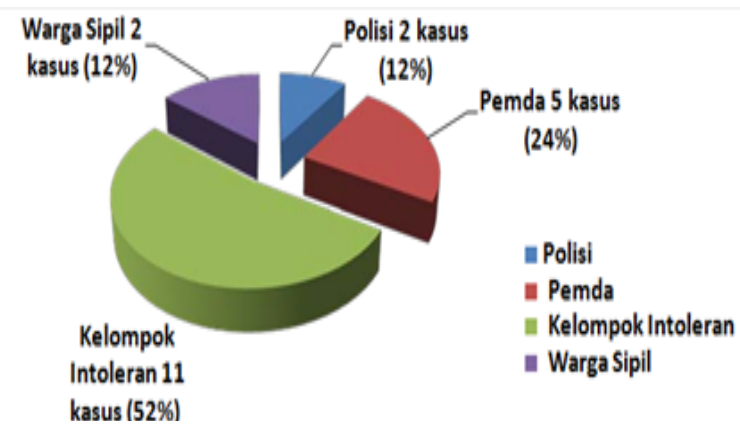

Figure 2 Perpetrators of violations of religious freedom

Perpetrators of violations in 2011 were dominated by local government officials, so in the 2017-2018 period most violations were committed by intolerant groups, with 11 cases of violations (52\%), while LGs were involved in five violation cases $(24 \%)$. The police are still involved in violations, although only two cases $(12 \%)$ were recorded, and two other cases were committed by civilians (12\%). 
While the victims, if in the period of 2011 the most experienced violations were the Ahmadiyah group, in the first quarter of 2012 the Christian group was the most violated, at least 8 cases of violations were experienced by them (38\%). The trust group ranks second as a violation victim $(19 \%)$, while Ahmadiyah is the third most victim with 3 violation cases $(14 \%)$.

Departing from the issue that seems increasingly difficult to solve these days, then through this paper the author will examine the problem:

a. Is religious freedom a form of protection for human rights in Indonesia?

b. What are the obstacles faced in realizing religious freedom as a form of protection of human rights in Indonesia and the efforts or solutions made by the government?

\section{RESULTS AND DISCUSSION}

\subsection{Religious freedom as a form of protection of human rights in Indonesia}

\subsection{1.. Manifestation of Religious Freedom in Society}

All religions teach noble values for the benefit of human life. Humans have played a role in renewing the role of religion in various regions of the world as an ideology of the public order so that in societies religious and political ideologies are interconnected. Religion has been used to achieve the interests of a particular person or group that has resulted in the politicization of religion in private and public areas. During the ideology and politicization of religion, violence in the name of religion cannot be avoided. Thus, the sanctity of religion has been reduced by a certain interest which will be dangerous for the peace of humanity itself. Therefore, in this case religion or God itself cannot be blamed. It is diverse people who have participated in bringing about violence by using the legitimacy of religion and God. Religion has been mixed with violent expressions of social aspirations, personal pride, and movements for political change.

The role of religion as a glue for heterogeneity and conflict reduction has long been questioned. It cannot be denied, that humans who inhabit this earth are so heterogeneous consisting of various tribes, ethnicities, races, adherents of religion, culture, civilization and so on. Samuel P. Huntington said that differences do not have to be conflicts, and conflicts do not necessarily mean violence. In its negative image, religion has contributed to the occurrence of conflict, oppression and violence. Religion has become tyrannical, where in the name of God people commit violence, oppression, injustice and murder.

\subsubsection{Freedom of Religion / Belief in International Human Rights Instruments}

Religious freedom other than listed in the Universal Declaration of Human Rights (UDHR), is found in various international historical documents on human rights, such as the Rights of Man France (1789), the Bill of Rights of USA (1791) and the International Bill of Rights (1966). Article 2 of the UDHR states: "Everyone has the right to all the rights and freedoms set forth in this Declaration without any exceptions, such as race, color, sex, language, religion, politics or opinions that differ, the origin of nationality or society. property rights, birth or other position.

In general, the UDHR announced by the United Nations in 1948 contained four basic rights. First, individual rights or rights that each person has. Second, collective rights or community rights that can only be enjoyed with others, such as the right to peace, the right to development and the right to a clean environment. Third, civil and political rights, among others, strengthen the rights that already exist in Indonesian legislation such as: the right to selfdetermination, the right to compensation for those whose freedom is violated; the right to life, the right to freedom of thought, belief and religion, the same right for women and men to enjoy civil and political rights, the right of a person to be informed of the reasons at the time of arrest, equality of rights and responsibilities between husband and wife, the right to freedom of expression. Fourth, economic, social and cultural rights, among others, strengthen the right to enjoy freedom from fear and poverty; prohibition on racial, color, gender, gender, and religious discrimination, equality between men and women to enjoy economic, social and cultural rights; the right to get a job; the right to fair wages for male and female workers; the right to form trade unions; the right to strike; the right to education: the right to be free from hunger.

The principle of freedom of religion and belief in the international human rights document is clearly stated in article 18: "Every person has the right to freedom of thought, belief and religion; this right includes freedom to change one's religion or belief, and freedom to practice his religion or belief in teaching, worship, worship and obedience, either alone or together with others, publicly or privately. "

The right to freedom of religion is also stated in more detail in the International Covenant on Civil and Political Rights article 18. The Covenant has been ratified by the Indonesian government through Law No. 12 of 2005 . Its contents are as follows: (1) Everyone has the right to freedom of thought, belief and religion. This right includes freedom to adhere to or accept a religion or belief of his own choice, and freedom, both individually and together with others, in public or closed places, to practice his religion or belief in worship, observance, practice and teaching; (2) No one may be forced to interfere with his freedom to embrace or accept a religion or belief according to his choice.

\subsubsection{Religious freedom as a form of protection of human rights in Indonesia.}

Human Rights (HAM) is a conception of humanity and social relations that was born from the history of human civilization throughout the world.

Recognition of Human Rights in Indonesia has been listed in the 1945 Constitution which actually existed earlier when compared with the United Nations Declaration which was born on December 10, 1948. Recognition of Human Rights 
in Indonesia has been listed in the 1945 Constitution and Regulations Other laws are as follows:

a. Opening of the 1945 Constitution First paragraph

b. Opening of the 1945 Constitution of the Fourth Paragraph

c. The body of the 1945 Constitution

d. Decree of the MPR. The MPR Decree on Human Rights is stated in MPR Decree No. XVII / MPR / 1998 Concerning Human Rights. Based on that, then Law Number 39 of 1999 concerning Human Rights was issued as a Law that was very important in relation to the process of Human Rights in Indonesia. In addition, Law Number 26 of 2000 concerning Human Rights Courts.

The 1945 Constitution of the Republic of Indonesia guarantees that everyone has the right to be free from discrimination. Even the 1945 Constitution of the Republic of Indonesia in full has guaranteed Human Rights (HAM) and also the rights of Indonesian citizens. The rights of citizens stipulated in the 1945 Constitution of the Republic of Indonesia constitute the Constitutional Rights of all citizens of the Republic of Indonesia, while the government should carry out the will of the people including guaranteeing the protection, enforcement and fulfillment of people's rights stipulated in the Constitution. This means that the State has an obligation and responsibility to guarantee that all the rights and freedoms of citizens are respected and fulfilled as well as possible without any discrimination. Republic of Indonesia State Law Number. 39 of 1999 concerning Human Rights (HAM) Chapter V in articles 71 and 72 explains that human rights with the rule of law cannot be separated. Justice and order and freedom of religion can be realized regardless of anyone. Thus, the recognition and protection and inauguration of the State that protects Human Rights for its citizens in religion must be recognized, respected and upheld.

\subsection{Constraints faced in realizing religious freedom as a form of protection of human rights in Indonesia.}

Religion occupies a sacred place which is an entity outside of humans. The obstacles faced in realizing religious freedom as a form of protection of human rights in Indonesia, namely:

a. Socio-Cultural Conditions

One factor hampering the enforcement of human rights in Indonesia is socio-cultural conditions. This is inseparable from the condition of Indonesia in the form of an island nation. With so many islands in Indonesia, there are also various customs, cultures, races, and ethnicities in Indonesia. Socio-cultural conditions that hinder the enforcement of law in Indonesia include:

1) The high application of customary law over national law so that some provisions actually violate the human rights of a community group, this causes the government and police officers to struggle to uphold human rights for these community groups.

2) The highly complex social status and stratification of the Indonesian population make human rights enforcement difficult.
3) The people's understanding of human rights is still low so that they are not aware when their rights have been violated.

4) Not many people are aware of the law and how important is the enforcement of human rights in life.

b. Communication and information

Communication and information is one of the causes of obstruction of human rights enforcement in Indonesia.

This is because :

1) The geographical condition of Indonesia, which consists of mountains, valleys, swamps and so on as well as the shape of the country in the form of an archipelago, makes it difficult to access communications and information to several regions.

2) Lack of adequate facilities and infrastructure covering all regions of Indonesia to communicate and disseminate information.

3) Not many educated and skilled human resources to solve communication and information problems in Indonesia. The limited information system used in Indonesia in terms of equipment and technology.

c. Government policy

In making policies, the government must be guided by national interests. Government policies are very influential on the enforcement of human rights. Some obstacles in the enforcement of Human Rights by the government:

1) Some government policies raise pros and cons in society because they are considered not biased to protect the rights of all citizens.

2) To maintain national stability, sometimes the government itself ignores the human rights of its citizens.

3) The absence of common principles or views about the importance of guaranteeing Human Rights by the authorities.

d. Legislation

The set of laws is also one of the causes of obstruction of human rights enforcement. The law referred to here is a written provision made by the central and regional government that is legal. Barriers to Human Rights by Legislation:

1) Some laws are ratification of the provisions stipulated in international conventions. Not all the contents of the provisions in the convention are suitable for application in Indonesia because of the different circumstances and conditions of the country.

2) There are laws and regulations that do not yet have implementing regulations which make it difficult for the police to enforce them.

3) There are several provisions in conflicting laws.

4) The absence of such comprehensive legislation can regulate all human behavior so that the majority of provisions are made after a problem occurs.

e. Officials and their actions

The officers referred to here are the police. The Republic of Indonesia Police have the duty to maintain the supremacy of Human Rights in accordance with the provisions contained in Law No. 2 of 2002 namely: 
3) Increasing efforts to prevent and overcome all forms of violence against women and women's human rights, evaluate and supervise the implementation of child protection. maintain and protect the security of the people, the order and the enforcement of law and human rights.

2) The Police of the Republic of Indonesia must maintain public security and property rights, and avoid violence in maintaining public order by respecting the supremacy of Human Rights.

3) The Republic of Indonesia Police in examining suspects must respect the principle of presumption of innocence as a suspect's rights until proven guilty by the court.

4) The Police of the Republic of Indonesia must comply with legal and religious norms to maintain the supremacy of Human Rights.

\subsection{Efforts are made in overcoming obstacles in realizing religious freedom as a form of human rights protection in Indonesia}

The Republic of Indonesia's police capacity as a state security tool and an institution that is part of the government system is required to carry out the order of the Act. Based on the Law, the National Police in carrying out their duties must uphold the principles of law enforcement, be independent (neutral, impartial), not intimidate, not spy, do not provoke or discriminate against a particular religious group. Instead the police must provide protection to every citizen and prevent acts of violence that will befall them and crack down on criminal behavior that acts anarchically in the name of a particular religion.

The efforts made by the government to overcome these obstacles are:

a. Form the National Human Rights Commission

The National Commission on Human Rights (Komnas HAM) was formed on June 7, 1993 by Suharto through Presidential Decree No. 50 of 1993. The position of the National Human Rights Commission then has a stronger legal force with the advent of Law No. 39 of 1999 which contains Human Rights. The purpose of the formation of the National Human Rights Commission:

1) Develop conditions conducive to the implementation of human rights in accordance with Pancasila, the 1945 Constitution, the Charter of the United Nations and the Universal Declaration of Human Rights.

2) Enhance the protection and enforcement of human rights

b. Establish Human Rights Instruments

The process of upholding and protecting human rights will be more secure with the presence of human rights instruments. Human Rights Instruments generally take the form of legislation and human rights enforcement agencies.

c. Establish a National Commission on Violence against Women

The objectives of the formation of this Commission are:

1) Socializing understanding of forms of violence against women

2) Creating conducive conditions by eliminating all forms of violence against women

d. Provide reports, input, suggestions, and considerations to the president regarding the implementation of child protection.

\section{CONCLUSIONS AND SUGGESTIONS}

Based on the results of the research and discussion, the researcher concludes that human rights arise from the belief that all human beings have the same degree. All communities have the same right to religion. For this reason, all religious communities must be treated equally. The realization of the protection of human rights in a country cannot be separated from cooperation from various parties, both citizens, police officers, and the government through regulations stipulated as social control.

\section{REFERENCES}

[1] Agustinus Edy Kristianto, Reflections on Religious Diversity: Heretical Law and Misleading Law, (Jakarta: YLBHI, 2009)

[2] Alamsyah M Dja'far, Ema Mukarramah and Febi Yonesta. Trying Belief: Study of the Decision of the Constitutional Court on the Law on Prevention of Blasphemy in Religion. Yogyakarta: Naufan Pustaka and ICRP (Indonesian Conference on Religion and Peace), 2011.

[3] Amin, Erik Irawan Hidayafatul Afidah, About Discrimination, (online) Accessed 29 April 2019

[4] Amin, Erik Irawan Hidayafatul Afidah, About Discrimination, (online) Accessed 29 April 2019

[5] Antone, Hope S. Contextual Christian Education: Consideration of the Reality of Diversity in Religious Education. Jakarta: BPK Gunung Mulia, 2010.

[6] Bahri, Saiful, Violations of Religious Minorities in Indonesia, (online), Accessed 30 April 2019

[7] Bahri, Saiful, Violations of Religious Minorities in Indonesia, (online), Accessed 30 April 2019

[8] Decade, Rome, Definition of Human Rights, (Online), accessed 30 April 2019

[9] Decade, Rome, Definition of Human Rights, (0nline), accessed 30 April 2019

[10] Eka A. Aqimuddin, 2009; Right to Religious Freedom; Between the Universal Declaration of Human Rights (1948) and the Cairo Declaration (1990) 
[18] Law No. 39 of 1999 concerning Human Rights (HAM)

[19] M. Thomas Thangaraj, Relating to People of Other Religions: What Every Christian Needs to Know, (Nasville: Abingdon Press, 2011)

[13] Gloria, Kezia, Protection of Human Rights in Indonesia, (online), accessed 29 April 2019

[14] Hope S. Antone, Contextual Christian Education: Consideration of the Reality of Diversity in Religious Education, (Jakarta: BPK Gunung Mulia, 2010)

[15] Kafid, N. ToR Gus Dur Memorial Lecture. Jakarta, 2011.

[16] Kristianto, Agustinus Edy. Reflections on Religious Diversity: Misguided Law and Misleading Laws. Jakarta: YLBHI, 2008.

[17] Law No. 2 of 2002 concerning the National Police
[20] Presidential Decree No. 50 of 1993 concerning the Position of the National Human Rights Commission

[21] Suparlan, Parsudi, 2008; Compound Communities, Multicultural Communities, and Minorities: Fighting for Minority Rights, paper presented at the Workshop on Intersection Foundation, Minority Rights in a

Multicultural Landscape, Is It Possible in Indonesia?, Wisma PKBI, August 10, 2008.

[22] Triyanto, 2008, Questioning Religious Freedom and Belief 